\title{
Correlation Analysis of Quality, Ability and Performance of Information Technology Usage on Registration Section of RSI Siti Rahmah Padang, Indonesia
}

\author{
Yanti Desnita Tasri ${ }^{a^{*}}$ \\ a) Academy of Medical Record and Information (APIKES) IRIS, Padang, Indonesia \\ *Corresponding author: zyri_bkt@yahoo.com
}

Paper History

Received: 25-August-2020

Received in revised form: 14-November-2020

Accepted: 30-November-2020

\begin{abstract}
Patient care in the registration section of the hospital is a very important activity, because there is a recording of patient data that will be used by other health workers in providing further health care. The use of information technology in the registration section can increase work effectiveness and efficiency and produce accurate information. For this reason, it is necessary to analyze the factors that affect the benefits of using information technology in the registration section. This study aims to examine the relationship between the quality of information systems, the ability of officers and the performance of information users at RSI Siti Rahmah Padang, Indonesia. The research was conducted with survey method and data analysis using a quantitative approach. From the research results, it was found that the quality of information systems did not affect the benefits of using information technology. Meanwhile, the ability and performance of officers affect the benefits of using information technology. It is suggested that the scope of the use of information technology in the medical records section be increased. It is necessary to increase the ability of officers in the use of information technology by holding training or workshops.
\end{abstract}

KEY WORDS: Hospital, medical records, information technology, registration performance.

$\begin{array}{ll}\text { NOMENCLATURE } \\ Y & \text { Benefits of information technology } \\ X 1 & \text { Quality of information systems } \\ X 2 & \text { Workability } \\ X 3 & \text { User performance } \\ a & \text { Constant } \\ e & \text { Confounding variable } \\ \beta 1 \beta 2 \beta 3 & \text { Regression coefficient }\end{array}$

\subsection{INTRODUCTION}

The development of information technology is currently very rapid and has reached various fields of life such as the field of health services in hospitals. The use of information technology serves to improve health service efforts in hospitals, by managing and organizing information related to patient data, reporting hospital activities. So, it can help health workers work more effectively and efficiently [1-3].

The use of information technology in the health sector has actually been started a long time ago. The Agency for Healthcare and Quality (AHRQ) in America is one of the institutions that initialize the use of information technology for research in the health sector ([4-6]. Information technology is an integrated method or tool that is used to filter data, process and transmit or present electronically into information in various formats that are beneficial to the user [7]. Information technology includes computing technology and communication technology, which is used to process and disseminate information for both in financial and non-financial [7].

Information technology used in the health sector is better known as health information technology (e-health), which supports activities in the health sector including: healthcare, health literacy, health research, health education and health knowledge [8-10]. Based on the Law of the Republic of Indonesia Number 44 of 2009 [11]: the hospital is a service 
institution for the community with its own characteristics that are influenced by health science, technological progress and the socio-economic life of the community. It must be able to improve services that are of higher quality and affordable to the community in order to create a complete health degree. The quality of service, especially medical services, is very important to be maintained in the hospital. One of the parameters to determine the quality of hospital medical services is the medical record services [12].

According to [13] the definition of service is a way of serving, preparing or guaranteeing the needs of a person or group of people. Serving is mean to take care of someone's needs from the time a request submitted until its delivery. According to the Indonesian Ministry of Health (2009) [11], "the definition of health services is an effort to organize individually or collectively in an organization to prevent and improve health, maintain and cure disease and also restore the health of individuals, groups, families and / or the public".

In an effort to improve the degree of health for the entire community, it is necessary to improve the quality of health services for patients accompanied by an increase in adequate supporting facilities. One way to improve the quality of service to patients is through improving services in the medical records section of each hospital or existing health service facility. A medical record officer at a hospital or health service facility has the duty and responsibility to manage patient data or records properly and safely. A patient file at a health care facility is known as a medical record. Medical records need to be managed properly because they are the main source of information for medical personnel in providing health care to patients and also a source of information for management in making decisions to improve the quality of health services.

Archives are records of activities or events in various forms and media in accordance with developments in information and communication technology created and accepted by state institutions, local governments, educational institutions, companies, political organizations, social organizations and individuals in the implementation of the life of the nation and state [14]. Given the importance of archives in an organization, archives must be managed properly and properly in accordance with the principles and objectives of archival management, namely being able to provide archives quickly, precisely, completely and efficiently [15]. Management is needed by organizations to manage records into appropriate information through work organizing activities. Electronic archive management makes it easier for archive users to find the required information again in the not too distant future [15-16].

The Siti Rahmah Islamic Hospital in the city of Padang is one of the organizations that provide health services to the public, with the aim of providing quality health services and information. In line with the development of information technology, the medical records in this hospital have managed the medical record archives of its inpatients using information technology. The purpose of this study is to analyze the effect of the quality of information systems on the benefits of information technology at Siti Rahmah Islamic Hospital, Padang, Indonesia. It is analyzing the effect of the ability of officers on the benefits of information technology, the effect of the performance of information users on the benefits of information technology at the Siti Rahmah Islamic Hospital, Padang.

\subsection{METHODOLOGY}

This research was conducted with a survey with a quantitative approach, which aims to examine the relationship between the quality, the ability of officers and the performance of information users to influence of the information system on registration section of Siti Rahmah Islamic Hospital in Padang. The research hypothesis was tested using multiple linear regression analysis that using a mathematical approach. Based on the conceptual framework, the following hypothesis is formulated:

- It is suspected that the quality of the information system has a positive effect on the benefits of information technology in the medical records section, particularly in the patient registration section at the Siti Rahmah Islamic Hospital, Padang.

- It is suspected that the ability of officers has a positive effect on the benefits of information technology in the medical records section, particularly in the patient registration section of the Siti Rahmah Islamic Hospital, Padang.

- It is suspected that the performance of information users has a positive effect on the benefits of information technology in the medical records section, especially in the patient registration section of the Siti Rahmah Islamic Hospital, Padang.

The population in this study was all medical record officers and management involved in the implementation of patient registration services at Siti Rahmah Islamic Hospital, Padang. The data used in this study are primary and secondary data. Primary data in this study is data obtained directly from respondents through distributing questionnaires. This primary data consists of respondents' responses to the statements on the research questionnaire.

To obtain relevant data and in accordance with the needs related to writing, the data collection techniques are:

- Literature study is studying and collecting data such as studying documents and books as well as annual reports from various literary sources that are related to research variables and the problems being studied to be used as basic materials for problem discussion.

- Questionnaires, namely data collection techniques by means of written questions and answers to respondents who are also answered in writing by the respondent. In this study, the questionnaire used was a structured questionnaire.

In this study, there are four variables were used:

1. Benefits of information technology: the benefits derived from using technology in processing and presenting information. Indicators of the benefits of information technology in this study are:

a. Labor efficiency

b. Increase competitiveness

c. Ease of compliance

d. Fast information delivery

e. Present information quickly.

2. Quality of information systems: the level of influence of using information systems on patient enrollment. Indicators of the quality of information systems in this study are: 
a. Thoroughly presenting information

b. Information as expected

c. Information always available

d. More accurate information

e. Quick in making decisions.

3. Officer ability: level of mastery of medical record officers in using information technology when providing services to patients. Indicators of the ability of information officers in this study are:

a. Easy to run

b. Have received training.

c. Usual soup to use

d. Easy to use

e. Have used the same system.

4. Information user performance: the results obtained by medical record officers after using information technology in carrying out their duties. The performance indicators of information users in this study are:

a. Get organized on duty

b. Increase work effectiveness

c. Saving time

d. Increase work quantity.

\subsection{RESULT AND DISCUSSION}

\subsection{Research Instruments}

The instrument used in this paper was distributed a questionnaire, which aims to obtain and find out the respondent's opinion. The statements given in the questionnaire are measured on a Likert scale. The Likert scale has a gradient from positive to very negative. The indicators, codes and variables of the research instrument can be seen in Table 1.

Table 1: Research Instrument Grid

\begin{tabular}{|c|c|c|c|}
\hline No. & Variable & Code & Indicators \\
\hline 1 & $\begin{array}{l}\text { Benefits of } \\
\text { information } \\
\text { technology }\end{array}$ & $\mathrm{Y}$ & $\begin{array}{l}\text { 1. Labor efficiency } \\
\text { 2. Increase competitiveness } \\
\text { 3. Ease of compliance } \\
\text { 4. Fast information delivery } \\
\text { 5. Present information quickly }\end{array}$ \\
\hline 2 & $\begin{array}{l}\text { Quality of } \\
\text { information } \\
\text { systems }\end{array}$ & $\mathrm{X} 1$ & $\begin{array}{l}\text { 1. Thoroughly presenting } \\
\text { information } \\
\text { 2. Information as expected } \\
\text { 3. Information always available. } \\
\text { 4. More accurate information } \\
\text { 5. Quick decision maker }\end{array}$ \\
\hline 3 & $\begin{array}{l}\text { Work } \\
\text { ability }\end{array}$ & $\mathrm{X} 2$ & $\begin{array}{ll}\text { 1. } & \text { Easy to run } \\
\text { 2. } & \text { Have received training. } \\
\text { 3. } & \text { Usual soup to use } \\
\text { 4. } & \text { Easy to use } \\
\text { 5. } & \text { Have used the same system }\end{array}$ \\
\hline 4 & $\begin{array}{l}\text { User } \\
\text { performance }\end{array}$ & X3 & $\begin{array}{l}\text { 1. Be organized in tasks } \\
\text { 2. Increase work effectiveness } \\
\text { 3. Save time } \\
\text { 4. Improve the quality of work }\end{array}$ \\
\hline
\end{tabular}

Furthermore, the testing of instruments was carried out to conduct Validity Test and Autocorrelation Test. The validity is defined as a measure of how carefully a test performs a function of its measure. A valid measuring instrument does not only reveal fixed data, but also must provide a description of the data An instrument or measuring test is said to have high validity if the measuring instrument performs a function or provides measurement results that are in accordance with the purpose of the measurement.

To determine valid and invalid item numbers, the following analysis test criteria were used:

- If the value of the correlation coefficient ( $r$ count) the score of each item with the total score is greater and equal to the value of $r$ table at the significance level $(\alpha=0.05)$, the instrument statement item is declared valid.

- If the value of the correlation coefficient ( $r$ count) the total score is smaller than the calculated $r$ value at the significance level $(\alpha=0.05)$, the instrument statement items are declared invalid / invalid.

The reliability test is a test that shows the extent to which the measurement can give relatively no different results when repeated measurements are carried out on the same subject. This test can only be done using the alpha formula or Crobach's Alpha. To find out how the effect of the independent variable (free) on the dependent variable (bound) in this study, multiple regression analysis is used. In this paper, to determine multiple linear equations with the formula:

$$
\mathrm{Y}=\mathrm{a}+\beta_{1} X_{1}+\beta_{2} X_{2}+\beta_{3} X_{3}+\mathrm{e}
$$

Furthermore, to find out the truth of the hypothesis, it is necessary to conduct the $\mathrm{t}$ test, $\mathrm{F}$ test and $\mathrm{R} 2$ test.

a. The t test is an individual regression coefficient test. This is to determine the ability of each variable to influence the dependent variable, by considering other variables to be constant.

b. The $\mathrm{F}$ test is used to test the significance of all regression coefficients together. The coefficient of determination (R2) and the coefficient of multiple correlations $(\mathrm{R})$

c. R2 is the coefficient of determination used to determine how much the dependent variation can be explained by the variation of the independent variable. Meanwhile, $R$ is the correlation coefficient $(R=\sqrt{R} 2)$ which is used to determine the closeness (strength and weakness) of the relationship between the dependent variable and the independent variable.

After the data is collected, then data analysis is carried out with the following steps:

- Normality test is done to check whether the data comes from a normally distributed population or not.

- Multicollinearity test is a relationship test among independent variables. Multicollinearity is a condition in which the independent variables in the regression equation have a strong correlation with each other. This analysis aims to see the correlation among independent variables. If there is a high correlation among the variables, then one of them will be eliminated or excluded from the multiple regression models.

- Heteroscedasticity test aims to test whether in a regression mode there is an inequality of variants from the residuals of one equation to other observations. 
Finally, the autocorrelation test was performed. The autocorrelation test was found: if there was a correlation between the disturbance variables, so that the estimator was no longer efficient both in small samples and in large samples.

\subsection{Validity and Reliability Test}

The results of the research are valid, if there is a similarity between the data collected and the data that actually occurs, on the object under study. A valid instrument means that the measuring instrument used to obtain the data is valid. Valid means that the instrument can be used to measure what should be measured. In this study, the validity or invalidity of an indicator can be seen at the Loading Factor value> 0.70 .

The results of research are reliable if there is a similarity of data in different times. A reliable instrument is an instrument that when used several times to measure the same object will produce the same data. In this study, to determine the reliability of an indicator can be seen in the Cronbach Alpha value> 0.70 . The results of testing the validity and reliability of the instruments for each variable can be seen in Table 2 .

Table 2: Results of Validity and Reliability Tests

\begin{tabular}{lcccc}
\hline \multicolumn{1}{c}{ Indicators } & $\begin{array}{c}\text { Loading } \\
\text { Factor }\end{array}$ & $\begin{array}{c}\text { Alpha } \\
\text { Cronbach }\end{array}$ & Validity & Reability \\
\hline $\begin{array}{l}\text { Information } \\
\text { system benefit }\end{array}$ & & & & \\
variables & & & & \\
\hline A1 & 0.834 & 0.829 & Valid & Reliabel \\
A2 & 0.779 & 0.867 & Valid & Reliabel \\
A3 & 0.769 & 0.837 & Valid & Reliabel \\
A4 & 0.771 & 0.865 & Valid & Reliabel \\
A5 & 0.831 & 0.845 & Valid & Reliabel \\
A6 & 0.765 & 0.839 & Valid & Reliabel \\
\hline Information & & & & \\
system quality & & & & \\
variables & & & & \\
\hline B1 & 0.871 & 0.865 & Valid & Reliabel \\
B2 & 0.773 & 0.766 & Valid & Reliabel \\
B3 & 0.735 & 0.768 & Valid & Reliabel \\
B4 & 0.772 & 0.784 & Valid & Reliabel \\
B5 & 0.763 & 0.745 & Valid & Reliabel \\
\hline Workability & & & & \\
variables & & & & \\
\hline C1 & 0.834 & 0.862 & Valid & Reliabel \\
C2 & 0.852 & 0.831 & Valid & Reliabel \\
C3 & 0.779 & 0.872 & Valid & Reliabel \\
C4 & 0.820 & 0.861 & Valid & Reliabel \\
C5 & 0.741 & 0.873 & Valid & Reliabel \\
\hline User & & & & \\
performance & & & & Reliabel \\
variables & & & & Reliabel \\
\hline D1 & 0.792 & 0.743 & Valid & \\
D2 & 0.576 & 0.729 & Valid & Reliabel \\
D3 & 0.826 & 0.734 & Valid & \\
D4 & & & & \\
\hline & & & & \\
\hline
\end{tabular}

Based on Table 2, it can be seen that the Loading Factor value of all indicators is $>0.70$, which means that all indicators in this study are valid. In the Alpha Cronbach column it can be seen that all indicators have a value $>0.70$ which means that all indicators in this study are reliable. Based on the results of testing the validity and reliability as a whole, the indicators in this study are suitable for use as a measuring tool.

\subsection{Regression Statistical Test}

The results of the regression statistical test in this study can be seen in Table 3.

Table 3: Regression Statistical Test Results

\begin{tabular}{lcccc}
\hline \multicolumn{1}{c}{ Variabel } & Coeffisien & thitung & $\begin{array}{c}\text { Prob } \\
(\mathrm{sig})\end{array}$ & Value \\
\hline $\begin{array}{l}\text { Quality of } \\
\text { information systems }\end{array}$ & 0.070 & 0.798 & 0.436 & \\
Officer capabilities & 0.174 & 2.360 & 0.031 & \\
User performance & 0.628 & 5.375 & 0.000 & \\
constant & & & & 25.662 \\
F $_{\text {sig }}$ & & & & 0.000 \\
$\mathrm{R}_{\text {square }}$ & & & & 0.98 .6 \\
\hline
\end{tabular}

Discussion of Regression Models

Several tests have been done before and it turns out that the regression model used is good, free from the disease of classical assumptions. The constant value $=25,662$ means that if the variables of information system quality, staff capability and user performance are constant, then the benefits of information technology are 25,662.

\section{Determination Coefficient Testing ( $R 2)$}

The coefficient of determination explains the variation in the influence of the independent variables on the dependent variable. Or it can also be said as the proportion of the influence of all independent variables on the dependent variable. In the results of this study, the R-square value is 0.98 .6 or $98.6 \%$, which means that 80.9 percent of variations in the ups and downs of the benefits of information technology are influenced by the quality of information systems, the ability of officers and user performance. The remaining of 1.4 percent is influenced by other variables outside the model.

\section{Simultaneous Significance Testing (F-test)}

The $\mathrm{F}$ test is the initial stage in identifying the regression model that is estimated to be feasible or not. Feasible (reliable) means that the estimated model is suitable to be used to explain the effect of the independent variables on the dependent variable. In estimating the data, an error tolerance level of $5 \%$ is used with testing criteria. In this study, the F probability value is 0.000 , which means that together the variables of information quality, information system quality, officer ability, and user performance have a significant effect on the benefits of information technology at RSI Siti Rahmah Padang.

Hypothesis Analysis ( $t$-test)

The t-statistic test is used to determine whether the independent variables (free) affect the dependent variable (dependent) or not. The $t$ test is often referred to as an individual test. In this study the degree of confidence used was $95 \%$ with an error rate $(\mathrm{a}=$ $0.05)$. Where, if the probability value (seen in the sig column) <alpha 0.05 then $\mathrm{HO}$ is rejected and $\mathrm{Ha}$ is accepted, whereas if the probability value (seen in the sig column)> alpha 0.05 then 
$\mathrm{H} 0$ is accepted and $\mathrm{Ha}$ is rejected.

Based on the results of the processed data in Table 3 it can be concluded as follows:

- Information quality variable has a probability of $0.436>0.05$, which means that the quality of the information system at RSI Siti Rahmah has no effect on the benefits of information technology.

- The officer ability variable has a probability of $0.031<0.05$, which means that the ability of the officer has a positive effect on the benefits of information technology.

- User performance variables have a probability of $0.000<0.05$, which means that user performance has a positive effect on the benefits of information technology.

\subsection{Classic Assumption Test}

The multiple linear regression models must be free from the problems of classical assumptions such as:

- Multicollinearity testing, the results of testing the Variance Inflation Factor (VIF) value show that there are no independent variables that have a VIF value greater than 10 . The results of testing the tolerance value also show this the same thing, namely the independent variable has a large tolerance value of 0.1 , which means there is no correlation between the independent variables. So it can be concluded that there is no multicollinearity between the independent variables in this regression model.

- Autocorrelation test, the results of the autocorrelation test can be concluded that in the linear regression model there is no autocorrelation.

- Normality testing, the results of the normality test can be concluded that the data in the study are normally distributed.

- Heteroscedasticity test, the test results can be concluded that there are no symptoms of heteroscedasticity.

Therefore, based on the research that has been done, the suggestions may provide: the scope of the use of information technology in the medical record section is increased because it can provide benefits in carrying out work in order to increase the ability of officers. So, they can improve the performance of the information technology used in line with technological developments. In increasing the capacity of officers, routine training should be carried out.

\subsection{CONCLUSION}

Based on the results of the research, all data are obtained free from the classical assumption test, namely the Normality Test, Multicollinearity Test, Heteroscedasticity Test and Autocorrelation Test. For the t-test, the value of the information quality variable has a probability of $0.436>0.05$, which means that the quality of the information system at RSI Siti Rahmah Padang has no effect on the benefits of information technology. The officer ability variable has a probability of $0.031<0.05$, which means that the officer ability has a positive effect on the benefits of information technology. The user performance variable has a probability of $0.000<0.05$, which means that user performance has a positive effect on the benefits of information technology. Testing the coefficient of determination (R2), the Rsquare value is 0.98 .6 or $98.6 \%$, which means that 80.9 percent of the variation in the ups and downs of the benefits of information technology. It is influenced by the quality of information systems, the ability of officers and user performance, while the remaining 1.4 percent is influenced by other variables outside the model. Simultaneous Significance Testing (F-test) is obtained the F probability value of 0.000 , which means that together the variables of information quality, information system quality, officer ability, user performance have a significant effect on the benefits of information technology at RSI Siti Rahmah Padang.

\section{REFERENCES}

[1] Negash, S., Musa, P., Vogel, D. \& Sahay,S. (2018). Healthcare information technology for development: improvements in people's lives through innovations in the uses of technologies, Information Technology for Development, 24(2), 189-197, DOI: 10.1080/02681102.2018.1422477.

[2] Asiamah, F.N. (2020). Improving the 'manager-clinician' collaboration for effective healthcare ICT and telemedicine adoption processes - a cohered emergent perspective, Information Technology for Development, 26(3), 525-550.

[3] Daerina, S., Mursityo, Y., \& Rokhmawati, R. (2018). Evaluasi peranan persepsi kegunaan dan sikap terhadap penerimaan sistem informasi manajemen rumah sakit (SIMRS) di rumah sakit daerah Kalisat, Jurnal Pengembangan Teknologi Informasi dan Ilmu Komputer, 2(11), 5950-5959.

[4] Kusumasari, L., Setianto, W.A. \& Pang, L. (2018). A study on digital democracy practice: opportunities and challenges of e-health implementation in Indonesia, Jurnal Ilmu Sosial dan Ilmu Politik, 22(1), 1-6.

[5] Hemmat, M., Ayatollahi, H., Maleki, M.R.. \& Saghafi, F. (2017). Future research in health information technology: a review, Perspectives in health information management, 14(1b), 1-19.

[6] Sittig, D.F., \& Singh, H. (2012). Electronic health record and national patient-safety goals, The New England Journal of Medicine, 367(19), 1854-1860.

[7] Muthmainnah, Fajriana, Siska, D. (2017). Pemamfaatan teknologi informasi untuk meningkatkan kualitas pembelajaran, Jurnal Techsi, 9(2), 65-77.

[8] Holt, K.A., Karnoe, A, Overgaard, D., Nielsen, S.E., Kayser, L., Røder, M.E. \& From, G. (2019). Differences in the level of electronic health literacy between users and non-users of digital health services: an exploratory survey of a group of medical outpatients, Interactive Journal of Medical Research, 8(2).

[9] Yang, S., Luo, Y. \& Chiang, C. (2017). The associations among individual factors, e-health literacy, and healthpromoting lifestyles among college students, Journal of Medical Internet Research, 19(1).

[10] Dixon, B., Barboza, K., Jensen, A., Bennett, K., Sherman, S., \& Schwartz, M. (2017). Measuring practicing clinicians' information literacy, Applied Clinical Informatics, 26(01), 149.

[11] Depkes RI. (2009). Profil Kesehatan Indonesia tahun 2009, Depkes, Jakarta. 
[12] Kencana, G., Rumengan, G \& Hutapea, F. (2019). Analisis kepatuhan pengisian berkas rekam medis di instalasi rawat inap rumah sakit X, Jurnal Manajemen Kesehatan Yayasan RS.Dr. Soetomo, 5(1), 27-37.

[13] Iskandar, S. (2016). Pelayanan kesehatan dalam meningkatkan kepuasan masyarakat di rumah sakit Pnglima Sebaya Kabupaten Paser, eJounal Ilmu Pemerintahan, 4(2), 777-788.

[14] Andriani, R. (2017). Analisis kesuksesan implementasi rekam medis elektronik di RS Universitas Gadjah Mada, Jurnal Sistem Informasi, Yogyakarta.

[15] Yusrawati (2015). Sistem informasi rekam medik elektronik di rumah sakit Bethesda Yogyakarta, Jurnal FIHRIS, 10(2).

[16] Peters, S.G. \&. Khan, M.A. (2014). Electronic health records: current and future use, Journal of Comparative Effectiveness Research, 3(5), 515-522. 